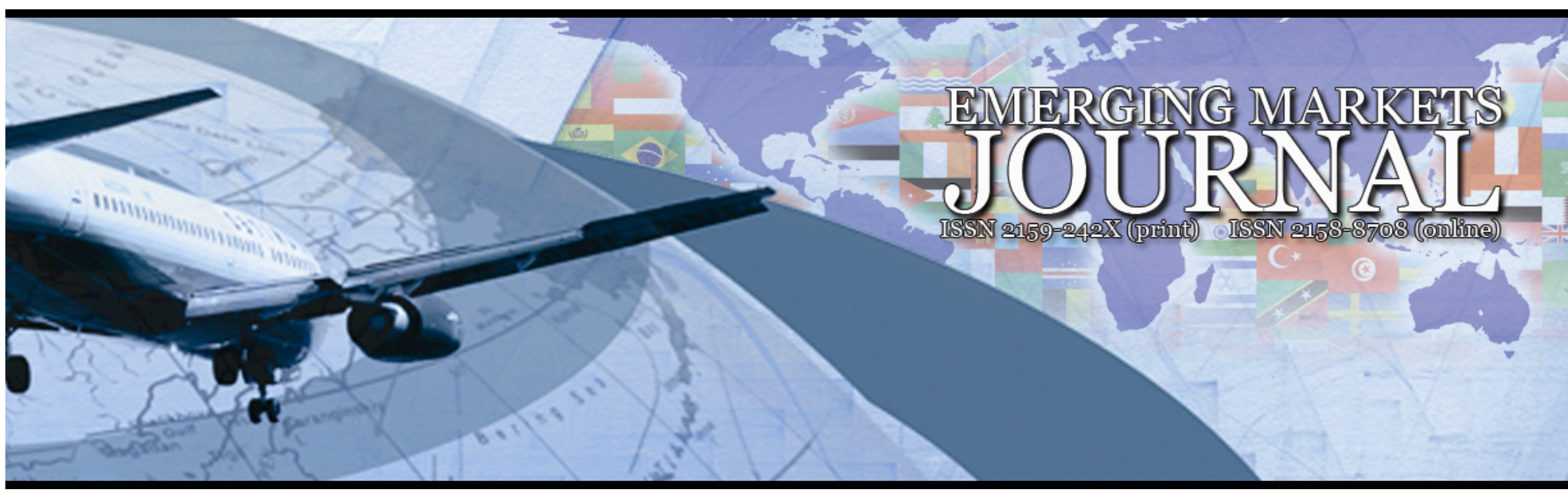

\title{
ENTRY MODES OF EUROPEAN FIRMS IN VIETNAM
}

\section{Daniel Simonet}

American University of Sharjah

e-mail: dsimonet@aus.edu

\section{Volume 2(2012) ｜ ISSN 2158-8708 (online) ｜ DOI 10.5195/emaj.2012.27 | http://emaj.pitt.edu}

\section{Abstract}

Purpose: The purpose of the paper is to explore the entry modes of EU firms setting up operations in Vietnam.

Design/methodology/approach: We use a case study approach on Haymarket, Cadbury, Creative Education, Fairchild, Aventis and Artemisinin and Farming International using interviews from managerial professionals in Vietnam.

Findings: Despite the fact that Vietnam has been opening up for more than 20 years, licensing is the preferred entry mode because of the risks involved in venturing with local firms; that preference signals a low level commitment and a high perception of risk and state interference. In line with Vietnam transition to state - rather than private market - capitalism, a foreign company opting for a joint-venture will do so with a state-owned rather than privately-owned company. The choice of a subsidiary can be explained by the lack of trust in partners and institutions, not by improvement in the socio-political environment.

Limitations: In determining the entry mode strategy, the paper focuses on the Uppsala school's "psychic distance" (e.g. cultural distance, lack of trust) rather than on firm-specific advantages (Rugman, 1980; 2006).

Key-words: international entry mode; emerging markets; subsidiary; joint-venture; India; Vietnam

\section{(cc) BY-NC-ND}

This work is licensed under a Creative Commons Attribution-Noncommercial-No Derivative

Works 3.0 United States License.

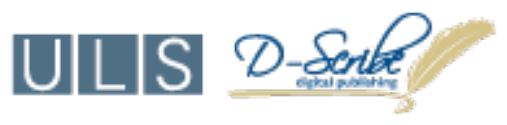

This journal is published by the University Library System of the University of Pittsburgh as part of its D-Scribe Digital Publishing Program, and is cosponsored by the University of Pittsburgh Press 


\section{Entry Modes of Europen Firms in Vietnam}

\author{
Daniel Simonet
}

\section{Foreign firms and the preference for private partners in newly-emerging emerging markets}

Reducing dependency remains a priority for foreign firms entering a newly-emerging, often adversarial market. That dependency ranges from access to markets, control over distribution channels, acquisition of business licenses, human capital, and government connections, the latter playing a prominent role in emerging markets. Government role can be positive, as documented in Russia where local governments use reforms to attract investments (Meyer and Pind, 1999), in China with the creation of special economic zones, and in India where states use tax incentives to attract foreign investment (Oman, 2000). It can also be restrictive: the government may impose a mandatory partnership with a local firm (e.g. Malaysia, Indonesia), or the purchase of locallymade components. Thus, firm operating within restrictive state-controlled environment will attempt to diminish government interference, thus might opt for a private rather than public partnership when possible. This is likely to be the preferred option if they have little experience managing government relations or, if they target a private - rather than public - market. Besides, dealing with private actors usually involves a variety of participants with different levels of power which the foreign firm can played against one another to extract better contracting terms: in the Vietnamese industrial equipment industry for instance, exclusive distribution agreements are limited to a period of 2 to 3 years (Tuang and Stringer, 2008), which enables foreign suppliers to shift to an alternative distributor should the need arise.

The number of stakeholder is also a factor. Contrary to democracies, where dealing with the public sector involves many stakeholders (e.g. interest groups, political parties, the mass media, citizen and consumer association), doing business in government-restricted markets involves fewer, often government-controlled, stakeholders. These can be more powerful, and thus put the foreign firm in a more dependent position. To eliminate that dependence, a foreign entrant may prefer a private rather than public - partner. Accountability and transparency are two other factors that make partnership with a private firm a more attractive option: while in free market and democratic countries, dealing with public organizations means a public display of accountability and frequent changes in officials; in contrast, the public service is less open to outside pressure and removal of ineffective public servants. By partnering with a private - rather than a public - company, a foreign firm can reduce those risks drastically (Dye, 2010).

Sound management of financial reserves is another reason to prefer a partner from the private sector. While public actors (e.g. elected officials) spend someone else's money, private individuals and business owners usually spend their own money, and will be more conscious when making investment decisions. Thus, partnership with private firms shall limit the risk of resource squandering, as accountability is greater with private business owners. Other factors such as monopoly (statutory or de facto), tendencies to over-spend and overregulate, failures in core roles (e.g. infrastructure), the pursuit of self-interest amongst both politicians and civil servants which leads to resource misallocation, decisions based on political rather than public benefits, all of which being more prevalent in adversarial - rather than mature markets, would in principle deter investors from partnering with public firms, thus makes partnership with a private firm a preferred option (Clemons et al., 2009; Post et al., 2002).

Reputation is a factor in emerging government-controlled economies. Fearing a boycott at home, foreign investors are wary of being associated with countries that are at odds with the international community, as this would affect their reputation at home. That happened to the French oil firm Total in Burma. That risk has become greater because information circulates more rapidly. Media pressure and reiterated calls for boycott by not-forprofit organizations can harm the reputation of a firm in its domestic market for actions conducted 
overseas. In contrast, supporting a private business is less likely to generate a similar backlash.

Another factor concerned planning horizon. Public budgets must be planned well in advance of the spending year. Private sector budgets are short-term, more flexible and can be adjusted: they can be remade just about any time management decides. That flexibility is another reason to prefer a private - rather than public - partnership.

P1 Firms entering a newly-emerging government-controlled market will prefer a partnership with a private - rather than public organization

However, a partnership with a government-linked company remains relevant in some occasions e.g. when the foreign firm target public buyers; when the private sector is still in infancy; or when the foreign entrant is public (i.e. a preference may be given to a partner with a similar culture)

\section{Time-horizon and the preference for high-equity entry modes}

There is another factor to consider: time horizon. In developing countries, there has been a shift in development strategies recommended by international money lenders (e.g. ADB) with a preference for long term projects and nation building. In these countries, capacity building has become the new mantra. Aid has shifted from economic infrastructure and services to increased emphasis on basic social services and public management capabilities (World Bank, OECD). Dominica and Rwanda exemplify the features of old and new style aid. Dominica, still receives about $80 \%$ of aid in form of economic infrastructure projects, such as roads, water supply, or irrigation. The aid programs of Rwanda have changed dramatically, with education, health and other social programs taking the lion's share (World Bank, OECD). In other countries, debt relief has become a major part of aid, relieving financial pressures of past, poorly-conceived or managed development programs. For foreign firms, as the time horizon of public development projects increases (which is also an indication of international lenders' commitment), risk intensity is not inherently less, but rather spreads over a longer period, thereby signaling that a short term loss could be offset on the long run. A foreign investor is more likely to adopt a high equity entry mode if it feels that the project duration is enough to recoup its investment, or if the benefits of the entry mode will fully materialize within a timeframe backed by an international institution. Hence, the longer the time horizon and project life cycle, the greater the commitment in the form of a more structured entry mode e.g. subsidiary. As international community support, investment visibility grow, and the host country gains socio-political stability (Urata and al, 2006), the perception of risk diminishes, and foreign firms are more inclined to increase their commitment in the form of a wholly-owned subsidiary e.g. foreign subsidiaries in China can be found in areas that offer the best long term prospects, as in the Pearl River Delta where major Japanese firms have established subsidiaries to serve the Guangdongi, Guangxi, Fujian and Hainan provinces.

P2 As the socio-political environment stabilizes, foreign firms will prefer a wholly-owned subsidiary over a low-equity entry mode (e.g. alliance, joint venture, partnership)

P3 As the time horizon of foreign investment expands, foreign firms prefer a whollyowned subsidiary over a low-equity entry mode (e.g. alliance, joint venture, partnership)

However, the time-horizon approach with its emphasis on long term projects underestimates rapid country changes: the Middle East, Turkey and North Africa region have emerged as promising off shore destinations because of their large, welleducated population and proximity to Europe in the late 2000s (AT Kearney). In particular, Cairo

\footnotetext{
In 2008, the Guangdong province alone contributed to almost 12 percent of China's national GDP, the largest of all provinces and municipalities, and to nearly $30 \%$ of China's total exports
} 
(Egypt) in North Africa has undertaken major infrastructure projects and administrative reforms to minimize risks to foreign investors. Rankings have changed in recent years: Dubai debt problem prompted foreign firms to consider alternative business hubs (e.g. Qatar, Bahrain) in the Middle East region, but these eventually stayed in Dubai as it provided political stability in the context of the Arab spring. In Southeast Asia, Thailand is no longer perceived as a safe investment destination due to its recent political turmoil and rioting.

Foreign firms' expectations and criteria to select a destination also vary over time. Years ago, the importance of host economy size and wealth, and more recently $\mathrm{MNC}$ agglomeration were major criteria when selecting a host country. Cheaper but skilled labor pools and tax incentives were also taken into consideration. But these criteria did not reflect certain risks (e.g. personal safety). South Africa, Nigeria, Pakistan, Kenya and Jamaica later proved unreliable, and criteria for selecting a country were amended. Current rankings of safest and riskiest places are now based on a wider range of factors which includes high terrorist or rebel threats, uncontrolled environmental pollution, corruption and organized crime, currency instability, geopolitical conditions cultural dissimilarities and unsecured communication networks: while India continues to be the most favored back-office of the world (Brown and Wilson 2009), it holds a precarious ranking in certain areas: unlike China, India's democratic society, and strong secondary stakeholders (e.g. free press and an active civil society which include NGOs, labor unions and politicians) will not hesitate to challenge foreign companies in courts, in the media, or via on site demonstration, especially when it involves land acquisition or other aspects of their livelihood (Vachani, 2008); Wal-Mart had to delay its entry in the Indian market because activists were concerned that the firm will hurt the livelihood of small traders. In addition, there are sectorspecific and country-specific criteria e.g. in the off shoring industry, similar time zone and language skills are critical factors due to the necessity to communicate with clients based in the West (e.g. British operators with Indian and Philippine callcenters; French operators with Tunisian and Moroccan call-centers). While the severity and complexity of country vulnerabilities has skyrocketed, firms often consider a - too - narrow set of criteria (e.g. typically country risk, competitiveness, costs) when selecting a foreign market.

\section{Investment delays and the preference for wholly- owned subsidiaries.}

Entry barriers can be a deterrent to jointventures: partners and service providers, particularly in the financial services, insurance and telecom sectors often demand hefty upfront payments. To this, add another constraint: time. Finding a suitable partner is difficult and timeconsuming in newly-emerging markets: after announcing its intention to enter the Indian market in 2002, Starbucks signed an agreement with Tata in 2004 to source premium coffee beans. However, in 2009, the company was still looking for a partner (it was rumored to be in talks with Jubilant Group, the Indian franchisee for Domino's pizzaii), and its entry in the Indian coffee market was delayed again. There are also country- rather than companyspecific - causes of delays such as a lack of confidence, uncertainty regarding economic performance and growth, as evidenced in Malaysia (Duasa, 2007) or in the pharmaceutical industry of Vietnam: while as many as 266 foreign businesses had registered to operate in Vietnam in $2005^{\mathrm{iii}}$, only $42 \%$ of combined investment capital of US\$ 240 million had been disbursed, and authorities had licensed just 35 foreign-invested projectsiv. For foreign firms, waiting is no longer an option: while years ago, adverse market conditions would prompt a foreign entrant to delay market entry, this is not possible because globalization makes the world faster: in a fast-paced environment, firms will be pressed to accelerate - rather than delay - their entry plan, even under adverse market conditions. To

\footnotetext{
i http://us.asiancorrespondent.com/indianomics/starbucks-inindia- $\% \mathrm{E} 2 \% 80 \% 93$-right-time-or-about-time

iii Source : Ministry of Health

${ }^{\text {iv }}$ VNECONOMY. Foreign pharmaceutical companies show interest in Vietnam. 26/09/2005.Source: Vietnam Agency.
} 
control local operations and avoid delays caused by ineffective partners, and to eliminate the risk associated with a joint-venture, and increase speed of entry, foreign firms will opt for an acquisition or the creation of a fully-owned subsidiary.

P4: Investment delay leads foreign investors to prefer a wholly-owned subsidiary over a joint venture in a newly-emerging market

\section{Effectiveness, opportunism and the preference for subsidiaries}

According to the Uppsala model (Johanson and Weidersheim-Paul, 1975), a high level of cultural distance between the country of origin and the target country is a deterrent to entry modes that involve high levels of ownership and control (Hill, Hwang and Kim, 1990). Cultural distance makes capabilities transfers more difficult: managers are reluctant to deepen involvement in markets they know little about, restrain their commitment (e.g. financial stake) when differences in values and beliefs between their home country and the host country are large, thus will prefer a joint-venture over a subsidiary in less culturally familiar environments (Erramilli and Rao, 1993; Gatignon and Anderson, 1988). There is an incremental expansion strategy encompassed in this school of thought: it implies a form of low commitment during initial entry (e.g. a licensing agreements has traditionally been a way to test a new market while keeping sunk costs low ${ }^{v}$ ), especially in market with greater "psychic distance" (e.g. differences in language education, business practices, culture and industrial development), and a greater commitment (e.g. subsidiary), as familiarity with the market develops (Sim, Rajendram Pandian, 2007).

While other scholars (Jung, 2004; Tatoglu, et al., 2003) too argue that "firms are more likely to

$\mathrm{v}$ as withdrawal is a possible occurrence in transition economies with changing regulatory frameworks have difficulties in managing foreign operations alone", Hymer (1960) and Shenkar (2001) assert that full ownership and the resulting total control allow managers to conduct business in their own way, which is thought to be more effective and straightforward than relying on local agents whose behavior is little known or cannot be predicted. Performance drivers such as local responsiveness or information flow are less effective in adversarial environment (Oliver, 1991): a local partner may be passive/dormant, act as a buffer between the foreign firm and the target market, thereby distorting critical information; maintain a hidden agenda (e.g. acquisition of foreign know-how before setting up a competing business), has harmful motives (e.g. a licensee may not develop the product of the licensor because of the NIH syndrome), or may acquire a license to prevent a foreign competitor from introducing a competing product (i.e. market preemption strategy), thus gain time to develop its own line of products (Simonet, 2002). Dues to these shortcomings, alliances were often ineffective: joint-ventures and other temporary transitional organizational form (Porter, 1990; Williamson, 1991) were either terminated or suffered from changes in the ownership structure (Yan \& Zeng, 1999) due to opportunism (Parkhe, 1993), and the unequal pace of learning (Larsson, Bengtsson, Henriksson, \& Sparks, 1998) with most exits by international joint ventures consisting in a sale to one of the partner firms or "internalization" (Hennart et al., 1998).

When newly-emerging markets open up to foreign investors, early entrants face a lack of potential partners, either because of the local firm's inexperience, or because of different strategic priorities at the country-level: for example, in contrast to other East Asian countries (e.g. Korea) that focus on competitive advantage in light industries (Lee, 2005), Vietnam has focused on its competitive advantages in agricultural (e.g. rice and coffee) and aquatic products, which create a dearth of potential partners in the industry and in the service sector. Though suitable partners may also be lacking because of potentially opportunistic behaviors, opportunism can be reduced in different ways e.g. repeated transactions with a small set of contractors; economies of scale and scope in transacting (e.g. a high volume of exchange between transactors); extensive inter-firm information sharing (e.g. to reduce information 
asymmetry); the use of non-contractual, selfenforcing safeguards (i.e., goodwill) which are effective for an indefinite time horizon (as opposed to contracts which are effective for a finite time horizon); key personal contacts with critical social capital and other factors (e.g. partner's customer orientation) (Truang and Stringer, 2008); and investments in co-specialized assets (e.g. a Free Trade Zone with the local partner providing manpower, assets and land). However, these mechanisms are difficult to find in unchartered markets e.g. transactions may be irregular due to economic and political disruption; newlyestablished privately-owned firms neither have a reputation of being trustworthy, nor a history of partnering (Nguyen, 2005) ; non-contractual safeguards are weaker in adversarial environments: the local partner may not have specialized assets to share (e.g. if the foreign firm is looking for nonspecific assets e.g. low-cost labor). Besides sharing specific assets is only a short-term temporary fix: it would still require a contract regarding availability and lease of equipment, which will generate transaction costs. Faced with a possible hostage-like situation (when sunk costs are high) or a lack of alternatives (e.g. when there are no substitute partners), foreign firms will opt for internalization (i.e. a subsidiary).

P5: In adversarial markets, effectiveness (i.e. ability to achieve a desired goal) and opportunistic partners leads foreign investors to prefer a subsidiary over a partnership

Contracts often serve an implicit function, acting as 'self-enforcing' agreements, and are often viewed as symbol of 'trust' (Telser, 1980; Sako, 1991), or goodwill (Bradach and Eccles, 1989; Sako, 1991). Trust can be defined as being "the firm's belief that another company will perform actions that will result in positive outcomes for the firm, as well as not take unexpected actions that would result in negative outcomes for the firm" (Anderson and Narus, 1990, p.45 in Tuang and Stringer, 2008). Trust is an essential element in reducing relationship and transaction costs (Dyer and Chu, 2003), particularly in emerging markets marked by weak safeguards and governance structures. When countries compete for foreign investment, the one with the lowest costs in relationship building will be selected Coase (1937) and Williamson (1975). Should these costs increase further, internalization (e.g. an acquisition, a startup, a subsidiary) will be preferred over a local partnership.

Trust and other factors (i.e. reputation) are effective safeguards when doing business. Private firms must devote time to develop new relationships and trust with partners (Nguyen TV et al, 2005). However, building trust is more difficult when significant income disparities exists (Wilkinson, Pickett, 2009), in countries at odds with the international community, or in transitional economies (Nguyen et al, 2005): in Vietnam, property rights are not well defined and private sector legitimacy is weak; market institutions and infrastructure are largely underdeveloped. A compounding factor, foreign governments might attempt to build legitimacy by blaming foreign governments for their own inadequacies, thereby generating more distrust between local and foreign organization.

Often, the level of trust depends on perceived fairness within the transaction. A lack of perceived fairness will result in higher transaction costs right from the start i.e. the response to injustice is "neglect" or a deterioration of conditions which lead to greater opportunistic behaviors (Husted, Folger, 2004). Fairness - or the lack of it leads to higher transaction costs, thus make it more difficult for MNC to achieve their objective when expanding overseas. In line with the transaction costs theory that suggests that firms minimize their costs as they grow, a subsidiary would eliminate monitoring costs in transaction whenever neglect is possible. When trust is lacking and when the transaction suffers from perceived unfairness, highequity modes should be preferred over low-equity entry modes. This also justifies takeovers: converting a joint venture into a wholly-owned subsidiary is more likely when there is a need to prevent neglect, for instance when conflict arises (Steensma et al, 2007).

Conversely, a greater level of trust and goodwill will prompt foreign firm to opt for a subsidiary: in the 1990s, a rapid familiarity with the emerging markets of Eastern and Central Europe (Estrin et al., 1997; Meyer, 1998) coupled with the European Economic Community's willingness to integrate these countries in the EEC to build political stability and peace following the collapse 
of the Soviet Union justified the preference for high-equity entry modes. In line with the Uppsala model, foreigners increase their commitment (e.g. subsidiary) in markets with limited "psychic distance", rising familiarity and trust (Sim, J. Rajendram Pandian, 2007):

P6. A wholly-owned subsidiary will be preferred in two opposite situations: either when the target market is unfamiliar and trust lacking, or when the target market is familiar and trust abundant.

\section{Company size and Experience}

Bargaining power affects firms differently, and depends on both company size and experience. Bargaining power exists between MNCs that have a preference for high-control entry modes, especially if the project is long-term; the government of the hosting country, which hopes to create jobs and earn tax; and the local firms that need foreign support to expand. Foreign firms have bargaining power because the newly-emerging markets of Vietnam, Cambodia and Laos vie with each other for foreign investments: "Despite being neighbors with close fraternal ties, no Indochina country ranks amongst the largest investors in another country of the sub-(Indochina) region,... three countries are competing with each other to attract FDI inflows" (Freeman, 2002b). Cambodia offers some unique advantages: "Foreign investors are allowed to own a company outright, without a local partner. There are no restrictions on funds transfers, no exchange controls and Cambodia is one of the few least-developed countries to have joined the World Trade organization ${ }^{\text {vi" }}$. Regarding size, Chen and Chen (1998) assert that large firms are better able to establish a position in primitive

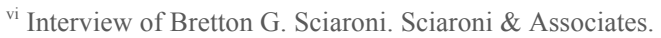
Phonm Penh. In Cambodia Is Hard Sell for Investment Companies. June 29, 2010 By Simon Marks. The New York Times
}

and non-institutionalized networks: “...members of the community often consist of multinational enterprises that individually generate global annual revenues that far exceed the annual GDP of some host countries, and have the trans-continental balance sheets to match..." (Freeman, 2002b). In a survey of tenant firms of a Vietnamese industrial park, the smaller companies view government regulations as the major constraint they encountered (in contrast, the larger companies cited competition for overseas competitors) (Yeoh et al, 2004). Parent firm size, possession of some knowledge-based and firm-specific strategic assets also prompt a firm to opt for entry modes with a higher degree of control (Tan et al., 2001): the larger the firm, the higher the propensity to adopt a high equity mode that allows full control (Leung et al., 2003).

For cultural differences and host country conditions reduce foreign firms' ability to extract valuable location-specific resources (Birkinshaw and Hood's 1998), the foreign entrant' experience is a factor in absorbing knowledge from its overseas acquisitions: a more experienced entrant will find it easier to manage cultural differences, or is more able to make a correct evaluation of a potential acquisition (i.e. cherry-picking). Thus, experienced - rather than inexperienced - foreign firms are more likely to opt for a wholly-owned subsidiary.

P7: A large and experienced entrant will prefer a wholly-owned subsidiary (i.e. internalization) over a low-equity entry mode when entering an newly-emerging market

However, this relationship does not appear uniform in Asia. In South-Asia in particular, large and experienced firms do not systematically opt for acquisitions: while Starbucks is a large and experienced entrant (years ago, it was a successful first entrant in the Japanese and Chinese markets), there is no indication of its intention to open a subsidiary in India. As for Gap, while its stores in other - more mature - retail markets such as Canada, France, Ireland, Japan, UK, and US (and Puerto Rico) are company-owned, stores outside of these countries are owned and operated by franchisees. Other large single-brand firm with significant international experience such as apparel retailers (e.g. Diesel, Tommy Hilfiger, Esprit, Louis Vuitton, FCUK, Lee Cooper, Escada, Guess, Dunhill, and Mango), mass-retailers (e.g. Marks \& Spencer, 
Debenhams, Next) and fast-food company (e.g. Pizza Hut) also entered the Indian market though the franchise route ${ }^{v i i}$. In contrast to India, will the large and experienced entrants of our case group adopt a wholly-owned subsidiary (i.e. internalization) when entering Vietnam?

\section{Asset specificity and capability Matching}

While cultural distance is a factor in choosing an entry mode, asset specificity is critical: according to Coase (1937) and Williamson (1975), if asset specificity and risk intensity are high, and transactions frequent, the firm will prefer internalization, and high-equity entry modes such as wholly-owned subsidiaries will prevail. Asset specificity in emerging economies has often been analyzed in terms of risks e.g. a local partner may copy an innovation or product (i.e. a tangible specific asset), dilute a brand (i.e. an intangible specific asset), or deteriorate the quality of a product. However, asset specificity should be viewed in terms of capacity matching: to make the partnership worthwhile, the local firm must have the capacity to absorb the capabilities of its foreign partner. In a newly-emerging market with greater psychic distance, the more specific the asset, the more difficult the absorption: a local firm in Laos, Vietnam or Cambodia may not have the technological know-how to maximum the use of the product of its foreign parent company, or the marketing skills needed to promote a foreign brand adequately. Imitation is less likely to occur when a foreign firm is unable to comprehend the value of an innovation it gets hold of, or unable to turn it to its advantage: simple imitation ignores what made the original great, as exemplified in the cargo-cult metaphor $^{\text {viii }}$. Capacity matching is a more critical

\footnotetext{
${ }^{\text {vii }}$ www.cci.in/pdf/surveys_reports/indias_retail_sector.pdf

viii During World War II, islands in the Pacific are were key locations for the belligerent and received large quantities of air-dropped supplies (e.g. food, weapons, medicine) destined to both Japanese and US troops. Some of these supplies were shared with the indigenous people who lived on the
}

factor than cultural distance when choosing a subsidiary.

P8 Capacity matching concerns - rather than cultural distance - will prompt a foreign firm to opt for a high equity entry mode in a newlyemerging market

Foreign firms often source for cheaper resources, moving their business to locations that are the most affordable: in response to increasing costs in the most advanced Asian countries (e.g. Singapore, Taiwan, Malaysia), MNCs have shifted their operations to China. Still, the rapid increase in wages has eroded China's attractiveness as a lowwage investment base and enticed Chinese firms to relocate labor-intensive manufacturing (e.g. clothing and footwear) lo lower wage neighboring countries. Chinese investors are already the largest investors in the Cambodian garment industry (Athukorala, 2008). Japanese firms have started shifting factories from China to Vietnam in response to strikes for higher wages ${ }^{i x}$. The degree of asset specificity foreign firm seek overseas will determine the entry mode in a host country: investors looking for non-specific resources (i.e. readily available and easily reproducible such as low-labor cost) will opt for a low-equity entry mode because it makes divestiture easier: they will then be more able to move their assets to a new location, if it offers lower labor costs. A low equity entry mode will be preferred when (i) asset specificity is

islands. When the war ended, they imitated what they saw , building large-scale replica of air-strips, bamboo control towers and straw planes, which was not good enough to bring the supplies back. They did not understand the underlying logic of the air-drop.

\footnotetext{
ix According to the Japanese External Trade Agency, Japanese direct investment in Vietnam that stood at 140 million dollars in 2009 have reached 1.1 billion over the first 5 months of 2010 .
} 
low (e.g. unskilled labor is widely available); (ii) there is a high need for re-deployability (e.g. should labor costs increase further). In contrast, investors in search of specific assets (i.e. rarer, more expensive, or demanding a higher mobilization of resources) will either set up a subsidiary, or acquire a firm in the host country. As a result, we expect to observe more low-equity entry modes when foreign firms look for assets that serve primary business needs (e.g. low labor costs), and more high-equity entry modes when foreign firms look for assets that serve more strategic or specific business needs.

P9: Foreign entrants in search of nonspecific assets will have a preference for a lowequity entry mode while foreign entrants in search of specific assets will opt for a high equity entry mode

\section{Agglomeration Effect}

When deciding upon entering a foreign market (Hymer, 1960; Caves, 1996), firms take into consideration the experience of other firms in their immediate business environment (Abrahamson and Rosenkopf, 1993). The agglomeration effect of foreign investment illustrate the need to build active local networks, which in turn will attract new network partners, either local or foreign (Krugman, 1991) (Audretsch and Feldman, 1994; Harrison, 1994) with DIs locating primarily in the vicinity of firms in the same industry, or from the same country of origin, as evidenced in China (Chen and Kwan, 2000). Foreign companies set up operations in geographic areas that benefited from earlier investments from similar developed countries, which leads to the formation of industry clusters. Though the core cities of Hanoi, Ho Chi Minh City and Hai Phong accounted for only $13 \%$ of the population in 1989 , they captured about $70 \%$ of joint-venture investments in all sectors, and their neighboring province only $20 \%$ (Nguyen and Meyer, 1999). Ho Chi Minh, which has accommodated foreign companies early on during the Doi Moi period, continues to be a magnet for foreign investors. Foreign investment are principally directed to areas that offer - not the cheapest - but the most literate and highly qualified labor forces (Nguyen and Meyer, 1999). In contrast to other emerging markets where foreign companies primarily invest in wealthier areas because of improved market prospects, foreign investors in Vietnam look primarily for provinces with higher quality manpower (i.e., higher level of literacy), even if those provinces are economically poorer (Nguyen and Meyer, 1999). As long as the population flow from the poor rural areas to the main cities remains constant, there is little need to relocate activities to the low labor-cost periphery. Overall, more educated workers and managers, easier access to information and market opportunities attract firms to the metropolitan areas (Tran Thi Bich, 2008). This legitimizes the building of industrial parks near the main cities (e.g. the Vietnam-Singapore industrial Park which has 124 tenants, 80 of which are in operations) (Yeoh et al, 2004). To this add other parks, either Vietnamese, such as the Viet Huong Industrial park, Song Than 1 and 2; Japanese (Thang Long 2 run by Sumitomo) or Korean or Taiwanese. Early movers have a strong incentive to help latecomers settle in these clusters because it increases their business network (e.g. in the form of business association) and enhances their bargaining power e.g. everyone want a stronger Chamber of Commerce to represent their interest and create a stronger resource pooling and exchange (Wassermanan, 1994) (Tsai and Ghoshal, 1998). Capitalizing on the experience of early entrants, late entrants also face less uncertainty when making an entry decision. Governments, including foreign and state-owned firms of the host country will also assist foreign investors in building local linkages in an effort to promote foreign investment (Yeoh et al, 2004). While these local linkages (e.g. to local private firms and communities) would traditionally consist in joint-ventures to acquire information (Inkpen and Beamish, 1997), a manager in a foreign market will be less willing to opt for a joint venture if it finds equally reliable ways to gather information i.e. via networks made possible by a greater internet access in the developing world; informal contacts with business and trade associations, companies from similar geographic origins; and knowledge transfers from expat returnees or locally-hired expats. These networks have grown significantly in recent years, and benefits late - rather than early - entrants.

P10 An early - rather than late - entrant will prefer a low-equity entry mode (e.g. JV, Licensing) when entering a newly-emerging market 


\section{Discussion}

After 14 years of socialist experimentation, Vietnam entered a new era with the Doi Moi. The country drafted its first banking reform and "was feted in Paris and Washington for his derring-do" (Beech, 2009). While Vietnam had all the characteristics of an adversarial market - an environment typically characterized by regulatory ambiguity, structural uncertainty and a weak legal system (Meyer, 1998; Peng, 2000), government regulations, institutional and historic ties, helped reduce adversity (Padmanabhan and Cho, 1996) and created a more stable and liberal environment. To this, add a more mature market the dynamic of which is better understood and easier-to-obtain business licenses. The creation of foreigninvestment zones signaled a warming up of relationships, and a return to economic and diplomatic normalcy e.g. "the formation of the Tan Thuan Export processing zone in 1989 was predicated on Vietnam quitting Cambodia, since a withdrawal was a precondition for normalizing economic relations with Vietnam" (Beech, 2009). Unlike other transitional economy (e.g. Russia), Vietnam has chosen a gradual path of "system improving" rather than a "shock therapy" for its transition to a market-based economy (Sachs and Woo, 1994): "mass privatization of state-owned enterprises does not seem to be necessary to create markets in Vietnam" (Lee and al, 2005). Looking at joint-venture formation, about 98 percent of jointventures have been made with State-Owned Enterprises (SOEs) (Le Dang, 2002). Several factors made SOEs attractive partners: transportation infrastructure serves state-owned firms efficiently (joint-ventures locate primarily in regions with many state-owned firms e.g. Ho-ChiMinh) (Meyer and Nguyen, 2005), making them attractive partners, and though one could have expected foreign firms to avoid areas with stateowned firms or national incumbents for fear of reprisals, foreign investors are willing to engage the latter as they provide access to government institutions (Meyer and Nguyen, 2005). For some (Nguyen TV et al, 2005), foreign investor can benefit from the state owned enterprises' preferential treatment (e.g. the government provides SOEs with subsidized bank loans). Foreign firms can also obtain financing from international financial institutions, as exemplified by Dutch
Lady, now known as Friesland Campina Vietnam Ltd who partly financed its JVs with loans from the finance arm of the World Bank i.e. International Financial Company (IFC). Ventures with local SOEs shall help circumvent domestic private sector's weaknesses and Vietnam's poor regulatory framework e.g. "the transition from a centrally planned economy to a socialist-oriented market economy implies two kinds of challenges: first, totally new fields, never covered, have to be regulated; and second, the subjects and institutions that have to cope with this work have developed in a different context and have no experience with aspects of a market economy" (Van Arkadie and Mallon, 2003) (Leproux, Brooks, 2004). To this, adds the discrimination against the private sector in terms of imports, technology and training (Thi Bich Tran et al, 2007), access to land and capital (i.e. contribution of property rights as equity in jointventures with foreign investors is conceded to SOEs but not to domestic private enterprises) and "equitization"x (i.e. most strategic enterprises have remained under government control) (Leproux, Brooks, 2004). These constraints have affected small and medium Vietnamese enterprises. Instead of growing organically, these expand by adding new contractors to their existing network (Nguyen et al, 2005). Politics is a factor (Masina, 2002). The emergence of a capitalist private sector may be perceived as a challenge to the state's authority and as a factor of political destabilization (Leproux, Brooks, 2004). This is not a single authoritative view. Others have argued that preservation of the state-run economy was to provide a safety net and give the private sector enough time to grow (Lee, 2000). Besides, partnering with state-owned companies is the not the panacea e.g. many are inefficient and had to be bailed out with government money or via bank loans (Van Arkadie and Mallon, 2003). That preference for SOEs contradicts our first proposition (P1 Firms entering a newlyemerging market will prefer a partnership with a private - rather than public - organization). An overwhelming majority of local partners of MNEs are public sector firms. Vietnamese authorities still

\footnotetext{
${ }^{x}$ In Vietnam, the privatization of state owned companies is called "equitization".
} 
discriminate against local, private firms which make SOEs more attractive for partnering. However, not all emerging markets in Indochina have given unfair advantages to the public sector: in contrast to Vietnam, Laos has aligned its FDI inflow with its privatization program; some of its 'flagship' stateowned enterprises (e.g. the country's telecommunications company, the Beer Lao brewery) were partially sold to foreign investors (Freeman, 2002b).

In our cases, foreign firms relied on opposite entry modes, with a preference for either a high-equity entry mode such as wholly-owned subsidiary, or a simple licensing agreement. Haymarket Media, one of the largest UK publishers in the UK, has launched its journals into Vietnam via a licensing system. In line with its transnational strategy, the parent company provides generic content (i.e. one that remains similar across its overseas editions) to its affiliated partners. The latter only adds local content. Haymarket Media intended strategy was twofold. Firstly, capitalizing on a 5 year old relationship, it intended to add new magazines to its partner's portfolio. Secondly, it looked for additional distributors to expand its readership. However, the company has an explicit 'licensing and syndication' strategy for its international magazines and content (over 40 editions of Haymarket's magazines published in Asia and a growing portfolio of online versions in Asia for a long time ${ }^{\mathrm{xi}}$ ) which are managed from its Hong Kong offices. There has never been any strategy to set up WOFS in Asia. Licensing is more appropriate than a subsidiary because asset specificity is low. The most specific asset (i.e. the journal content) already exists and is owned by the foreign firm. Rather than creating new specific (i.e. localized) asset (i.e. content), the firm make existing asset 'sweat' i.e. generate more cash by selling the same content to new overseas markets. These

\footnotetext{
${ }^{x i}$ In China, simplified Chinese; Hong Kong, traditional Chinese; India - Gujarati; Indonesia - Bahasa Indonesian; Japan Japanese; Korea, South - Korean; Malaysia - English; Philippines - English; Singapore - English; Taiwan Traditional Chinese; Thailand - Thai; Vietnam Vietnamese.
}

licenses are not strategic, but confined to one stage of the value chain (i.e. marketing and sales). The only intangible specific asset consists of connections with publishers and advertisers.

The same can be observed in the yachting industry (e.g. Fairchild' licensing agreement aimed at obtaining an access to potential yacht buyers and politicians to build marinas in touristy areas) and in education with Creative Education: foreign entrants rely on low-equity entry modes when looking for assets with low specificity (e.g. buildings or classrooms). Though these firms were first entrants $^{\text {xii }}$, they did opt for a low-equity entry mode, which supports our proposition (P10 an early rather than late - entrant will prefer a low-equity entry mode when entering a newly-emerging market). The same applied to Cadbury. Though an early entrant in the emerging Vietnamese confectionary sector, it shunned the creation of a joint-venture, preferring a simple distribution agreement. Only when foreign firms seek more specific assets, do they look for a more complex form of cooperation (e.g. a joint-venture, a whollyowned subsidiary), which support our earlier proposition (P9: "foreign entrants in search of nonspecific assets will prefer a low-equity entry mode while foreign entrants in search of specific assets will opt for a high equity entry mode"). For instance, Sanofi created the Sanofi-Pharma Vietnam joint venture in 1992 with Usine 23, one of the major national pharmaceutical companies. Aventis Pharma International established the Roussel Vietnam Joint Venture in 1993 as a 40/60 jointventure with Sapharco. Both were looking for specific resources (e.g. medicinal plants to be used in $R \& D)$, which justified a higher equity stake.

\footnotetext{
xii In particular, Fairchild was a first entrant in the nascent yachting market: unlike Taiwan, Vietnam has no yachting industry and lacks basic infrastructure (e.g. marinas, engineers, skippers, after-sales maintenance).
} 
IX. Cultural differences, opportunism and subsidiary creation

In Vietnam, joint-ventures proved disappointing. In the earlier year of the Doi Moi period, foreign investors sought partnership with local Vietnamese firms, and joint ventures were to overcome inefficient bureaucracy, acquire market and business information (Griffith, Zeybek, and O'Brien 2001) (Erramilli and Rao, 1993), and lower foreign entrant' sunk costs (Root, 1987). However, joint-ventures lacked flexibility and many ended up in disputes because the minority partner could and did exercise significant power on his foreign partner e.g. Sapharco purchased the stake held by French partner to turn Roussel Vietnam into a $100 \%$ locally-owned company in 2002. To this, add the meddling of ministries and provincial authorities if the local partner is a state-owned enterprise, and the fear that a partner may eventually become a competitor. A compounding factor were differences in law: ownership status will determine which law to apply because different laws regulate the private and state sectors (CIE, 1998), (Nguyen TV et al, 2005) e.g. in a survey of tenant firms of a Vietnamese industrial park, the smaller ventures cited government interference as the major constraint they encountered (in contrast the larger wholly-owned companies cited competition for overseas competitors) (Yeoh et al, 2004). In such a high-risk environment, firms are less likely to cooperate (Carlier and Tran, 2005). As Thi et al (2008) observed, while 30 percent of firms in the 1996 sample relied on a network of subcontractors, that percentage decreased to 18 percent in 2001 . This supports proposition 6 (e.g. a subsidiary will be preferred when the target market is unfamiliar and trust lacking). Conversely, when trust abounds, contracts are not a priority. Because of the trust it had in its partners, Creative Education thought that contract would be of limited value in the Vietnamese context, thus it neither created a subsidiary, not opted for a joint-venture. When trust exists, contracts are believed to be superfluous.

Being patient and blending into the local culture is critical to success. The risk however is to try too hard to play with the local rules; that is to leave one's own comfort zone, "change the way one would normally operate, and eventually do business in a way that would be considered irrational at home" (Creative education). In retrospect, inefficient partners and cultural misunderstanding in Vietnam suggest that foreign firms would be better off by choosing a wholly-owned subsidiary, as these have lower failure rates. From 1988 till November 1997, the failure rate of investment projects in all sectors was $16 \%$ in Vietnam (694 investment projects were dissolved out of 4,514 projects $)^{\text {xiii }}$. The failure rate of joint ventures is thought to be at least twice as much (Thu, 1998). The number of equity-based relationships (e.g., joint ventures) and other business relations between foreign investors and private sector companies has been fairly disappointing (Freeman, 2002a): $60 \%$ of the registered FDI was not used in $2006^{\text {xiv }}$. The slow FDI implementation has been attributed to factors such as inadequate infrastructure, management problems and a shortage of adequately trained human resource ${ }^{\mathrm{xv}}$. With feedback and experience from previous entrants, late entrants prefer subsidiaries over joint-ventures and other lowequity entry modes. The former represents a higher fraction of foreign investment in Vietnam, with $61 \%$ of licensed projects compared to $34.3 \%$ of licensed projects for joint ventures (Le Dang, 2002). The same can be observed in China. Joint-ventures are no longer the preferred entry mode. In 2004, wholly-owned subsidiaries accounted for $65 \%$ of entry modes in 2004 (24\% for the period 1979$1996)$ compared to $30 \%$ for equity joint venture (61 $\%$ for the period 1979-1996), and $5 \%$ for cooperative venture (15\% for the period 19791996). This supports proposition 10 (P10 Early entrants will opt for a low-equity entry mode while late entrant will opt for a high-equity entry mode when entering a newly-emerging market), but contradicts proposition P2 (As the socio-political

\footnotetext{
xiii e.g. there has been a high number of high-profile withdrawal cases such as Chrysler's abandonment of a car plant, or the withdrawal of Total from a refinery project

xiv http://www.economywatch.com/foreign-directinvestment/countries/vietnam.html

xv http://www.economywatch.com/foreign-directinvestment/countries/vietnam.html
} 
environment stabilizes, foreign firms prefer subsidiaries over joint ventures). The preference for subsidiaries can be explained by the lack of trust in partners and institutions, not by improvement in the socio-political environment. In the education venture for instance, even if there was a genuine commitment (the local partner made significant investments e.g. in the form of a new building, by providing an operating license while the foreign partner provided Hanoi-based foreign staff, curriculum, teacher training, recruitment and management services and proprietary knowledge e.g. course syllabus), the local firm omitted significant financial information in its dealings with the British education provider. Major cultural differences also emerged during the negotiations process: under the belief that personal relationships were more important, that a contract has little legal value (though their symbolic value cannot be dismissed), the British education provider engaged in lengthy negotiations before withdrawing from the venture after months of negotiation. A subsidiary would have eliminated those risks, as exemplified by the many other education service providers that have since set up WOFSs in Vietnam. For instance, British International School caters to expatriates' children and local children from wealthy families. ILA Vietnam is a $100 \%$ foreign-owned education and training company that provides English language programmes. To this add university pathway programmes, corporate training and teacher training. RMIT International University has remained the only foreign university to operate $\operatorname{solo}^{\mathrm{xvi}}$.

Only when investment are stake are large, do foreign firm seek a partner: wholly-owned foreign enterprises accounted for $32.8 \%$ of FDI value in 2002, and joint-ventures for 53\% of FDI value. Foreign firm would go alone, if it were not for the size of the investment. Besides, the reason for opting for a subsidiary might also not fall under the Uppsala school's of "psychic distance" (e.g. lack of trust in partners and institutions, opportunistic behaviors, and cultural differences, etc): large number of MNEs set up 100\% wholly

\footnotetext{
${ }^{x v i}$ It has a student body of approximately 5,000
}

owned foreign subsidiary (WOFS) from scratch e.g. Nestle (food), Prudential (life insurance and financial services), etc. (just to name a few European companies as this paper focuses on European companies) because they possess strong firm-specific-advantages (capital, brand, marketing, management, international experience in new venture start up, and ability to hire good experienced local personnel, etc.) that no local firm can match, which supports P8 (Capacity matching concerns - rather than cultural distance - will prompt a foreign firm to opt for a high equity entry mode in a newly-emerging market).

\section{$\mathrm{X}$. The time horizon issue}

In contrast to proposition 3 "As the time horizon of foreign investment expands, foreign firms prefer a wholly-owned subsidiary over a lowequity entry mode (e.g. alliance, joint venture, partnership)", a long-term view does not prompt foreign investors to opt for a subsidiary. In our cases, no firm opted for a subsidiary because of investment delay, and many maintained they strategy of licensing because of the lack of efficient patent protection in Vietnam: though licensing out is a low-risk/return alternative that provides little control, it enables the licensing firm to make a rapid entry and obtain some, but not all return on investment when facing potential future copycats (Rajshekhar and Wright, 2003).

In contrast to earlier research studies (Davidson, 1980; Agarwal and Ramaswami, 1992) that states that newly-emerging markets are more likely to attract experienced - rather than inexperienced - firms, and that firms with international experience have a preference for high equity entry modes (e.g. wholly-owned entry modes), firms in our group cases did not opt for a subsidiary in Vietnam: in 2006, Cadbury Schweppes signed a distribution agreement with Vietnam's leading food maker Kinh Do, one of the largest confectionary companies in Vietnam, giving it access to its distribution network. Despite a longterm business strategy, a double-digit market growth in Vietnam and a strong international experience, Cadbury commitment did not extend as far as far as opening a subsidiary from scratch. Only in more mature - but still emerging - market was an 
acquisition a better option for the British company. In Brazil, Cadbury acquired Adams, a giant confection company with distribution channel and a decent share of the market. Perhaps, this was the only option at the time. In 2006, when it entered into the distribution agreement with Kinh Do, the parent firm itself was confronted with a take-over bid from Kraft Food, which left the company with few resources, and opening a subsidiary in Vietnam was not an option at this time. It is the more inexperienced and smaller entrants (e.g. foreign entrepreneurs) who opted for a wholly-owned subsidiary in Vietnam, as exemplified by the privately-owned firm Artemisinin and Farming International (AFI) in the anti-malarial industry. This is in line with concurrent observations in the Cambodian and Laotian hospitality sector (Hipsher 2008), and earlier observations in Honduras (Befus, 1988): foreign entrepreneurs often launch their own small firm in a foreign country ("foreign-born firm"). As Hipsher (2008) notes, the lack of government regulations, the lower sunk costs, the less intense competition and the informal nature of the economy encourage entrepreneurs to start a subsidiary from scratch. Traditional barriers to entrepreneurship in mature markets (e.g. access to capital, business experience, and competition on market) are not as high in less developed foreign markets. Most often, subsidiary creation is based on personal factors: a short term exposure to the country (as an expat working in the country or during travel / leisure time), an entrepreneurial mindset, the "need to do something" in an environment that provide little employment opportunities and where self-employment is seen as a poverty-reduction strategy. However, full ownership could not prevent opportunism. AFI had to relocate its activities (e.g. farming, postharvesting, and extraction) from the Red River Basin of Northern Vietnam to northern Thailand due to difficulties in controlling costs. Compounding factors were ineffective middle-men, unsecured transaction prices, problems in accessing land and obtaining local funding of working capital. Thus, neither proposition 7 (A large and experienced entrant will prefer a wholly-owned subsidiary (i.e. internalization) over a low-equity entry mode when entering a newly-emerging market), nor proposition 5 ("In adversarial markets, effectiveness i.e. ability to achieve a desired goal and a higher opportunism risk leads foreign investors to prefer a subsidiary over a jointventure") are supported.

Country - rather than international experience is a factor when switching to a highequity entry mode. Converting a joint venture into a wholly-owned subsidiary is more straightforward for country-experienced firms: Aventis and SanofiSynthelabo set up two joint-ventures Aventis Vietnam, formerly known as Vinaspecia, and Sanofi-Pharma Vietnam in 1992. As Sanofi's market experience grew, the firm raised its initial $50 \%$ stake in the company to $70 \%$ in June 1995 . As for Aventis, it ended its joint-venture with its Vietnamese partner i.e. Sapharco to set up a wholly foreign-owned company in Vietnam in 2002. Acquisition of local knowledge was a factor in increasing the drug firm financial stake (Puck et al., 2006). As for Aventis, the conversion to a subsidiary will put an end to the discrepancy in resources brought by partners, which supports proposition 8 "Capacity matching concerns - rather than cultural distance - will prompt a foreign firm to opt for a high equity entry mode in a newlyemerging market". It also appears than when transactions imply highly specific assets, as in the pharmaceutical industry, firms will opt for highcontrol modes (e.g. subsidiaries) regardless of environmental uncertainty. In 2000, on 24 foreign projects invested in the Vietnamese pharmaceutical industry, there were 15 enterprises with $100 \%$ foreign investment capital and 8 joint ventures only (Invest Consult Group, 2002). Wholly owned subsidiary have become more prevalent because of the potential of the Vietnamese market due to its sheer size (87 million people), central location (Vietnam is increasingly used a base for exporting drug product to neighboring countries of Laos and Cambodia) (Simonet, 2008) and rapid growth (health expenditure has been growing at more than $10 \%$ annually and the drug market at $4.5 \%$ per annum) (WPM Outlook, 2005). That is in line with earlier work: Makino and Neupert (2000) found that strong market growth prompts managers to prefer wholly owned subsidiaries over joint ventures.

Conclusion: We note the high number of simple agreements (e.g. licensing) in our cases. After more than 20 years of economic and diplomatic opening, one would have expected that trust would flourish, and that foreign entrants would display a greater level of commitment and a 
preference for high equity entry modes. However, in a country that is gradually liberalizing but is still heavily government regulated, one that is growing fast but is as yet a developing country with uncertainty about the economic conditions, licensing agreements still prevail, even among large and experienced firms: Joint venture had outcomes below expectations, and subsidiary creation is no guarantee for success. The preference for low equity entry mode (e.g. licensing) signals foreign firms' reluctance to commit to the Vietnamese market, despite its potential (in terms of customer base, growth rate). In Vietnam, the life cycle of the Uppsala model has a longer life span than anticipated, with foreign firms' exploratory phase lasting more than 20 years. In contrast to European firms that have entered eastern European markets with full-fledged subsidiaries, managers go through extensive testing in Vietnam, relying on lowcommitment entry modes to gain a foothold in the market, even after its 20-years transition to capitalism, perhaps because of the nature of Vietnamese capitalism: it is a state - rather than private - capitalism. It remains to be seen whether the preference for entry modes with low-sunk costs will constitute a hurdle in the development of the Vietnamese economy, or if it will protect it from foreign competitors until a strong domestic private sector emerges. 


\section{References}

1. Anderson, J.C. and Narus, J. (1990), “A model of distributor firm and manufacturer firm working partnership", Journal of Marketing, Vol. 54, pp. 42-58.

2. Audretsch, D.B. and Feldman, M.P. (1994), External economies and spatial clustering, in P. Krugman and A. Venables (Ed.), The Location of Economic Activity: New Theories and Evidence, Centre for Economic Policy Research: London.

3. Abrahamson, E. and Rosenkopf, L. (1993) Institutional and competitive bandwagons,

4. A Miner, A.S. and Haunschild, P.R. (1995) Population level learning, Research in Organizational Behavior Vol. 17, pp. 115-166. Academy of Management Review Vol. 18, pp. 487-517.

5. Agarwal, S. and Ramaswami, S.N. (1992), “Choice of foreign market entry”, Journal of International Business Studies, Vol. 23(1), pp. 1-27.

6. Chandra, A.P. (2008). "Trends and Patterns of Foreign Direct Investments in Asia: An Interpretative Survey". in The Future of Economic Integration in Asia in economics 2007 proceedings of the , Thammasat University and Japan bank for International Cooperation, 2008.

7. AT Kearney Global Service Locations Index 2007

8. Beech Hannah. About turn. Time. Vol 173, n 26/27, 2009.

9. Befus, D.R., Mescon, T.S., Debbie, L. and Vozikis, G.S. (1988), “International investment of expatriate entrepreneurs: the case of Honduras”, Journal of Small Business Management, Vol. 26 No. 3, pp. 407.

10. Birkinshaw, J. and Hood, N. (1998), Multinational subsidiary evolution: capability and charter change in foreign-owned subsidiary companies, Academy of Management Review, Vol 23 No.4, pp. $773-795$.

11. Bradach, J. L. and R. Eccles (1989). Markets versus hierarchies: From ideal types to plural forms, Annual Review of Sociology, Vol. 15, pp. 97-118.

12. Brown and Wilson (2009). Black book of outsourcing, Year-of-Outsourcing-Dangerously.

13. Carlier, A. and Tran, S. (2005). Promoting Business to Business Commercial Contracts in Vietnam, World Bank Policy Note, Hanoi.

14. Caves (1996). Multinational Enterprises and Economic Analysis, 2nd ed., Cambridge University Press, New York, NY.

15. Chen, H. and Chen, T.-J. (1998), "Network linkages and location choice in foreign direct investment”, Journal of International Business Studies Vol. 29 No.3, pp. 445-468.

16. Chen, L.K. and Kwan, Y.K. (2000) "What are the determinants of the location of foreign direct investment? The Chinese experience”, Journal of International Economics, Vol. 51, No. 2, pp.379400 . 
17. CIE, (1998). "Enterprise Reform Project”, in Canberra and Sydney (Ed.), Center for international economics.

18. Clemons R. S. and McBeth M. K. (2009), Public Policy Praxis: A Case Approach for Understanding Policy and Analysis, 2nd Edition, Coase, R.H. (Ed.) (1937), The nature of the firm, Economica N.S, Vol. 4, pp. 386-405, in Stigler, G.J and Boulding, K.E. (Eds.), Price Theory, Irwin, Homewood, pp.386-405.

19. Davidson, W.H. (1980) "The location of foreign direct investment activity: country characteristics and experience effects”, Journal of International Business Studies, Vol. 11 No.2, pp. 9-22.

20. Duasa J. (2007). “Foreign Direct Investment And Growth: Does Stability Matter?” Journal of Economic Cooperation Among Islamic Countries, Vol. 28 No.2, pp. 83-98.

21. Dye T. (2010), “Understanding Public Policy. International Edition 13th Edition”

22. Dyer J.H. and Chu W. (2003). "The Role of Trustworthiness in Reducing Transaction Costs and Improving Performance: Empirical Evidence from the United States, Japan, and Korea”. Organization Science, Vol. 14, No. 1, pp. 57-68.

23. Erramilli, M.K. and Rao, C.P. (1993) "Service firm's international entry-mode choice: a modified transaction-cost analysis approach”, Journal of Global Marketing, Vol. 57, pp.19-38.

24. Saul E., Hughes K. \& Todd S. (1997). Foreign Direct Investment in Central and Eastern Europe, Cassel, London.

25. Freeman, N.J. (2002a). Foreign direct investment in Vietnam: an overview', DFIP Workshop on Globalisation and Poverty in Vietnam, Hanoi.

26. Freeman, N.J. (2002b). Foreign Direct Investment in Cambodia, Laos and Vietnam: A Regional Overview. Conference on Foreign Direct Investment: Opportunities and Challenges for Cambodia, Laos and Vietnam, Hanoi.

27. Gatignon, H. and Anderson, E. (1988). “The multinational corporation's degree of control over foreign subsidiaries: an empirical test of a transaction cost explanation”, Journal of Law, Economics and Organization, Vol. 4 No. 2, pp.305-336.

28. Griffith, D. A., Zeybek, A.Y., and O'Brien, M. (2001). "Knowledge Transfer as a Means for Relationship Development: A Kazakhstan-Foreign International Joint Venture Illustration", Journal of International Marketing, Vol. 9 No.2, pp. 1-18.

29. Harrison, B. (1994), Lean and Mean: The Changing Landscape of Power in the Age of Flexibility, Basic Books, New York, NY.

30. Hennart, J. F.,Kim, D. J. and Zeng, M. (1998). The Impact of Joint Venture Status on the Longevity of Japanese Stakes in U.S. Manufacturing Affiliates, Organization Science Volume 9 No. 3, pp. 382-395.

31. Hill, C.W.L., Hwang, P. and Kim, W.C. (1990). "An eclectic theory of the choice of international entry mode”, Strategic Management Journal, Vol. 11, pp.117-128. 
32. Hipsher S. (2008). "Born foreign firms in Cambodia Exploration of mode of entry decisions of firms originating from the greater Mekong sub-region”, International Journal of Emerging Markets, Vol. 3 No. 1, pp. 104-115

33. Hymer, S. (1960) The International Operations of National Firms: A Study of Direct Investment, PhD Thesis, MIT Press, Cambridge.

34. Husted, BW and Folger, D. (2004). Fairness and Transaction Costs: The Contribution of Organizational Justice Theory to an Integrative Model of Economic Organization, Organization Science, Vol. 15 No. 6, pp. 719-729.

35. Inkpen, A.C. and Beamish, P.W. (1997). Knowledge, bargaining power and the instability of joint ventures, Academy of Management Review, Vol. 22 No. 1, pp.177-202.

36. Invest Consult Group (2002) Report on Vietnam Basic Chemical and Pharmaceutical Market, May.

37. Johanson, J. and Weidersheim-Paul, F. (1975), “The internationalization of the firm: four Swedish cases”, Journal of Management Studies, Vol. 12 No. 3, pp. 305-22.

38. Jung, J. (2004). "Acquisitions or joint ventures: foreign market entry strategy of US advertising agencies", The Journal of Media Economics, Vol. 17, No. 1, pp.35-50.

39. Krugman, P. (1991). Geography and Trade, MIT Press, Cambridge, MA.

40. Larsson, R., Bengtsson, L., Henriksson, K. \& Sparks, J. (1998). “The interorganizational learning dilemma: Collective knowledge development in strategic alliances”, Organization Science, Vol. 9 No.3, pp. 285-305.

41. Le Dang, D. (2002) Foreign direct investment in Vietnam: results, achievements, challenges and prospects, international monetary fund, Conference on Foreign Direct Investment, Hanoi.

42. Leproux V and Brooks D.H. (2004). "Viet Nam: Foreign direct Investment and Postcrisis Regional integration”, working paper No. 56, September.

43. Leung, S., and J. Riedel, (2001). "The Role of the State in Vietnam's Economic Transition”, working paper, Technical Report Economics of Development, APSEG, Australian National University.

44. Lee K. (2005). "Late Marketization vs. Late Industrialization: Convergence or Divergence in East Asia",Asia-Pacific Journal of Economic Literature, Vol. 19 No. 1, pp. 42-59.

45. Leung, M.K., Rigby, D. and Young, T. (2003). Entry of foreign banks in the people's republic of China: a survival analysis, Applied Economics, Vol. 35, pp.21-31.

46. Makino, S. and Neupert, K.E. (2000). "National culture, transaction cost, and the choice between joint venture and wholly owned subsidiary”, Journal of International Business Studies, Vol. 31, pp.705713.

47. Masina, P. (2002). Rethinking Development in East Asia, Curzon Press, Nordic Institute of Asian Studies. Surrey.

48. Meyer, K.E. (1998). Direct Investment in Economies in Transition, Elgar, Aldershot. 
49. Meyer KE and Pind C. (1999). The slow growth of foreign direct investment in the Soviet successor states, Economics of Transition, Vol. 7 No.1, pp.135-50.

50. Nguyen, H.V. and Meyer, K.E. (2005). "Foreign investment strategies and sub-national institutions in emerging markets: evidence from Vietnam”, Journal of Management Studies, Vol. 42, No. 1, pp.63-95.

51. Nguyen, V.T., Weinstein, M. \& Meyer A.D. (2005). "Development of trust: A study of inter-firm relationships in Vietnam”, Asian Pacific Journal of Management, Vol. 22No. 3, pp.211-235.

52. Oliver, C. (1991). Strategic responses to institutional processes, Academy of Management Review, Vol. 16, pp. 145-179.

53. Oman C. (2000). Policy Competition for Foreign Direct Investment: A Study of Competition Among Governments Attracting FDI, OECD, Paris.

54. Padmanabhan, P. and Cho, R.K. (1996). Ownership strategy for a foreign affiliate: an empirical investigation of Japanese firms, Management International Review, Vol. 36 No. 1, pp.45-65.

55. Pandian, S.J.R. (2007), “An exploratory study of internationalization strategies of Malaysian and Taiwanese firms”, International Journal of Emerging Markets, Vol. 2 No. 3, pp. 252-273.

56. Parkhe, A. (1993). "Strategic alliance structuring: A game theoretic and transaction cost examination of interfirm cooperation", Academy of Management Journal, Vol. 36 No.4, pp. 794-829.

57. Peng, M.W. (2000). Business Strategies in Transition Economies, Sage: Thousand Oaks, CA.

58. Porter, M. (1990). The competitive advantage of nations. New York: Free Press

59. Post, James E.; Lawrence, Anne T.; Weber, James. Business and Society: Corporate Strategy, Public Policy, Ethics, 10th Edition Boston, McGraw-Hill/Irwin.

60. Puck, J.F., Holtbrügge, D. and Mohr, A.T. (2006). "Beyond entry mode choice: explaining the conversion of joint ventures into wholly-owned subsidiaries in the PRC", in AIB Southeast Asia Regional Conference 2006 proceedings of the conference in Bangkok, Thailand 7-9 December.

61. Rajshekhar, J. and Wright, R. (2003) “An international market entry model for pharmaceutical companies: a conceptual framework for strategic decisions”, International Journal of Medical Marketing, Vol. 3, No. 4, pp.274-286.

62. Jonathan, R.(2005). Living with Transition in Laos: Market integration in Southeast Asia. Routledge, Abington.

63. Root, F.R. (1987). Entry Strategies for International Markets, Lexington Books, Lexington, MA.

64. Rugman AM, 1980. "Internalization as a general theory of foreign direct investment: A re-appraisal of the literature," Review of World Economics (Weltwirtschaftliches Archiv), Springer, vol. 116(2), pages 365-379, June.

65. Rugman AM \& Sukpanich N, 2006. "Firm-Specific Advantages Intra-Regional Sales and Performance of Multinational Enterprises," Working Papers 2006-19, Indiana University, Kelley School of Business, Department of Business Economics and Public Policy. 
66. Sachs J, Woo WT, Fischer S and Hughes G. (1994). Structural Factors in the Economic Reforms of China, Eastern Europe, and the Former Soviet Union Economic Policy, Vol. 9 No. 18, pp. 101-145

67. Steensma K, Jeffrey Q. Barden J, Dhanara C, Lyles M and Tihany L. (2007). “The evolution and internalization of international joint ventures in a transitioning economy”, Journal of International Business Studies, pp. 1-17.

68. Sako, M. (1991). The role of "Trust" in Japanese buyer-supplier relationships, Ricerche Economiche, Vol. 45 No.2-3, pp. 449-474.

69. Shaver, M. and Flyer, F. (2000). "Agglomeration economies, firm heterogeneity and foreign direct investment in the United States”, Strategic Management Journal, Vol. 21, pp. 1175-1193.

70. Shenkar, O. (2001). "Cultural distance revisited: towards a more rigorous conceptualization and measurement of cultural differences”, Journal of International Business Studies, Vol. 32, pp.519-535.

71. Simonet D. (2008). "The Vietnamese pharmaceutical market: a comparison of foreign entry strategies”, International Journal of Business and Emerging Markets, Vol. 1 No. 1, pp. 61.

72. Simonet D. (2002). “Licensing agreements in the pharmaceutical industry”, English version published in International Journal of Medical Marketing. Vol. 2 No.4, pp. 329-341.

73. Smith, D.A. (1996). Third World Cities in Global Perspective: The Political Economy of Uneven Urbanization, Westview, Boulder, CO.

74. Tatoglu, E., Glaister, K.W. and Erdal, F. (2003). Determinants of foreign ownership in Turkish manufacturing, Eastern Europe Economics, Vol. 41 No. 2, pp.5-41.

75. Telser, L. G. (1980). “A theory of self-enforcing agree-ments”, Journal of Business, Vol. 53 No.1, pp. 27-44.

76. Tan, B., Erramilli, K. and Liang, T.W. (2001). The influence of dissemination risks, strategic control and global management skills on firms' modal decision in host countries, International Business Review, Vol. 10, pp.323-340.

77. Tran Thi Bich, Grafton R. and Kompas, T. (2008).”Firm Efficiency in a Transitional Economy: Evidence from Vietnam", Asian Economic Journal, Vol. 1 No. 22, pp. 47-66.

78. Tuang $A$ and Stringer C. Trust and commitment in Vietnam: the industrial distributor's perspective. International Journal of Emerging Markets. Vol. 3 No. 4, 2008. pp. 390-406.

79. Thu, T. (1998). New wave to improve investment climate, Saigon Times, pp.22-25.

80. Thu, T. (1998). New wave to improve investment climate, Saigon Times, pp.22-25.

81. Tsai, W. and Ghoshal, S. (1998). "Social capital and value creation: the role of intra-firm networks", Academy of Management Journal, Vol. 41 No.4, pp. 464-476.

82. Urata S, Chia Siow, Y. and Fukunari, K. (2006). "Multinationals and Economic Growth in East Asia Foreign Direct Investment, Corporate Strategies and National Economic Development. Routledge International Business in Asia Routledge, UK.

Entry Modes of Europen Firms in Vietnam 
83. Vachani S. India: opportunities and challenges for multinational enterprises" International Journal of Business and Emerging Markets, Vol. 1,No. 1, pp. 42-59.

84. Van Arkadie, B., and Mallon R. (2003). Vietnam: A Transition Tiger? Australian National University Press, Canberra.

85. Wasserman, S. and Faust, K. (1994). Social Network Analysis: Methods and Applications, Cambridge University Press: Cambridge.

86. Williamson, O. (1975) Markets and Hierarchies: Analysis and Antitrust Implications,

87. The Free Press, New York.

88. Williamson, O. (1991). Comparative economic organization: the analysis of discrete structural alternatives. Administrative Science Quarterly, Vol. 36 No.2, pp. 269-296.

89. Wilkinson RG and Pickett KE. (2009). The Spirit Level: Why More Equal Societies Almost Always Do Better. Penguin, London.

90. Outlook WPM. (2005). World Pharmaceutical Markets, Vietnam.

91. Yan, A., \& Zeng, M. (1999). “International joint venture instability: A critique of previous research, a reconceptualization, and directions for future research", Journal of International Business Studies, Vol. 30 No.2, pp. 397-415.

1.YEOH C, WONG D and Wong SY (2005). "A Note on Singapore's Pursuit of Location Advantages in Indonesia and Vietnam", Asia-Pacific Journal of Economics and Business, Vol.5, 8, 1, pp. 4459. 